\title{
Parvovirus and 'weepy red' axillae
}

Ignatius Losa

Department of Paediatrics, Macclesfield District Hospital, Macclesfield, UK

\section{Correspondence to}

Dr Ignatius Losa, ignatius.losa@nhs.net

Accepted 9 September 2014

\section{DESCRIPTION}

A 10-year-old boy presented with 10 days history of upper respiratory tract infection, generalised aches, rash and 2 days history of fever. There was no history of recent foreign travel or infectious contacts.

On examination, he had generalised erythematous maculopapular and petechial lesions (figure 1). There was no conjunctivitis or mucosal changes or enlargement of lymph glands or liver or spleen. There were no palatal petechiae.

A couple of days after presentation, the erythematous macular lesions in the axillae had become more florid and with bleeding areas (figures 2 and 3). The rashes were not typical of the commonly known 'glove and stocking' distribution of parvovirus.

The white blood cell and platelets counts were low but recovered back to normal after 2 weeks.

The viral serology was positive and confirmed acute infection with parvovirus and antibody to B19 DNA was detected by PCR (15 603835 copies/mL $(\log =8.19)$.

No biopsy was undertaken and he clinically fully recovered and has remained well.

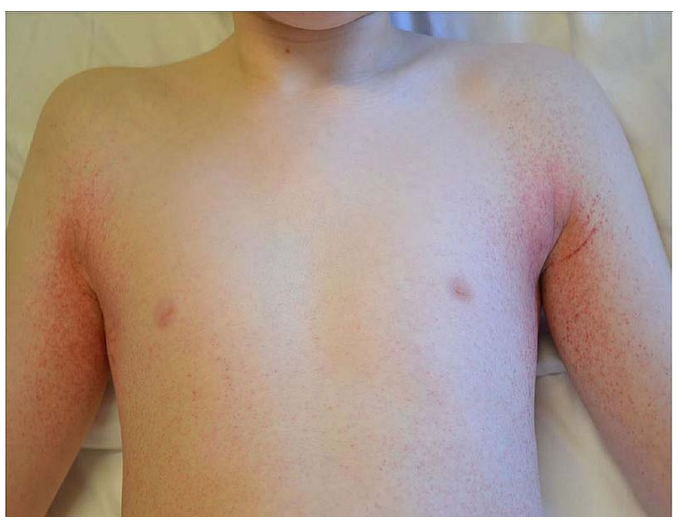

Figure 1 Trunk of child showing generalised rash.

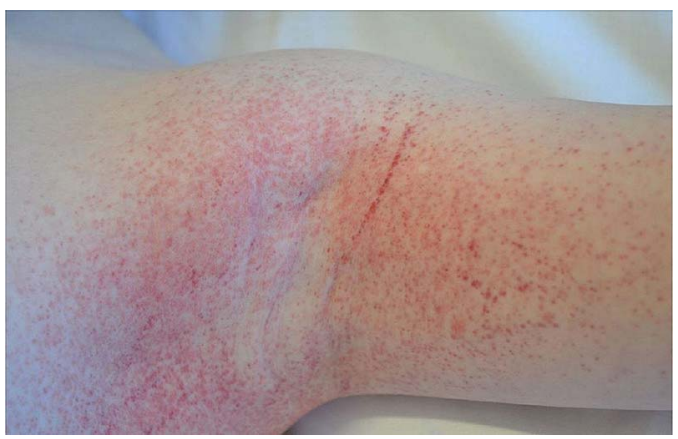

Figure 2 Left axilla showing haemorrhagic lesions.

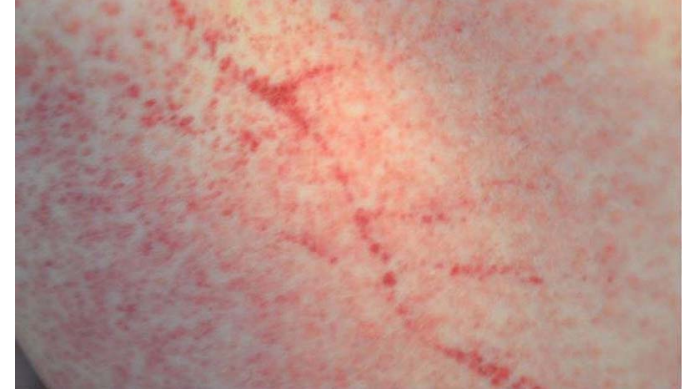

Figure 3 Close up of haemorrhagic lesions in right axilla.

Parvovirus infection is an acute viral exanthem with parvovirus B19 and is transmitted via respiratory tract droplets. The incubation period is $13-18$ days. The most commonly described rashes are slapped cheek in appearance, and also generalised maculopapular enanthem and the 'glove and stocking' distribution are commonly described. There have been very few reports of petechiae or purpuric rashes. ${ }^{2}$

Haemorrhagic lesions are rarely reported. ${ }^{3}$

Other possible causes of haemorrhagic skin lesions include other viral enathems, meningococcal disease, infectious mononucleosis, Kawasaki's disease, thrombocytopenic purpura and bone marrow defects.

Haemorrhagic exudation is an unusual presentation of parvovirus skin manifestation.

\section{Learning points}

- Parvovirus is a common childhood infectious illness. It can present with generalised exanthema. It can result in transient marrow aplasia.

- Parvovirus infection can mimick Kawasaki's disease or streptococcal infection.

- This report highlights the need for parvovirus to be considered in the differential diagnosis of acute haemorrhagic lesions associated with fevers.

\section{Competing interests None.}

Patient consent Obtained.

Provenance and peer review Not commissioned; externally peer reviewed.

\section{REFERENCES}

1 Harms M, Feldmann R, Saurat JH. Papular-purpuric "gloves and socks" syndrome. J Am Acad Dermatol 1990;23(5 Pt 1):850-4.

2 Chinsky JM, Kalyani RR. Fever and petechial rash associated with parvovirus B19 infection. Clin Pediatr (Phila) 2006;45:275-80.

3 McNeely M, Friedman J, Pope E. Generalized petechial eruption induced by parvovirus B19 infection. J Am Acad Dermatol 2005;52 (5 Suppl 1):S109-13. 
Copyright 2014 BMJ Publishing Group. All rights reserved. For permission to reuse any of this content visit http://group.bmj.com/group/rights-licensing/permissions.

BMJ Case Report Fellows may re-use this article for personal use and teaching without any further permission.

Become a Fellow of BMJ Case Reports today and you can:

- Submit as many cases as you like

- Enjoy fast sympathetic peer review and rapid publication of accepted articles

- Access all the published articles

- Re-use any of the published material for personal use and teaching without further permission

For information on Institutional Fellowships contact consortiasales@bmjgroup.com

Visit casereports.bmj.com for more articles like this and to become a Fellow 